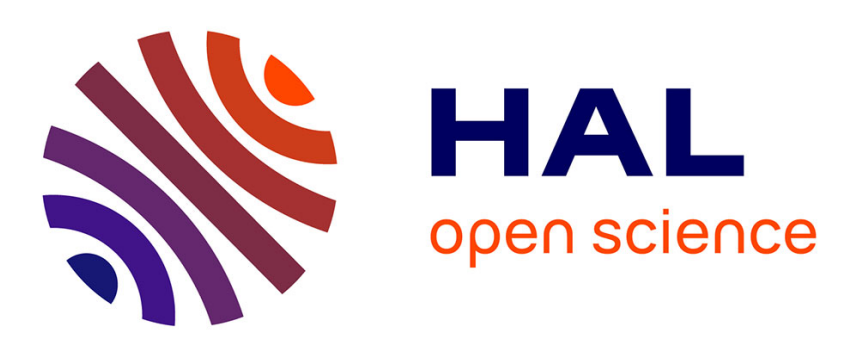

\title{
Effect of reactive mechanical grinding on chemical and hydrogen sorption properties of the $\mathrm{Mg}+10 \mathrm{wt} . \% \mathrm{Co}$ mixture.
}

Jean-Louis Bobet, Bernard Chevalier, Jacques Darriet

\section{- To cite this version:}

Jean-Louis Bobet, Bernard Chevalier, Jacques Darriet. Effect of reactive mechanical grinding on chemical and hydrogen sorption properties of the $\mathrm{Mg}+10 \mathrm{wt} . \%$ Co mixture.. Journal of Alloys and Compounds, 2002, 330-332 (1-2), pp.738-742. 10.1016/S0925-8388(01)01580-8 . hal-00070916

\section{HAL Id: hal-00070916 https://hal.science/hal-00070916}

Submitted on 30 May 2012

HAL is a multi-disciplinary open access archive for the deposit and dissemination of scientific research documents, whether they are published or not. The documents may come from teaching and research institutions in France or abroad, or from public or private research centers.
L'archive ouverte pluridisciplinaire HAL, est destinée au dépôt et à la diffusion de documents scientifiques de niveau recherche, publiés ou non, émanant des établissements d'enseignement et de recherche français ou étrangers, des laboratoires publics ou privés. 


\title{
Effect of reactive mechanical grinding on chemical and hydrogen sorption properties of the Mg+10 wt.\% Co mixture.
}

\author{
J.-L. Bobet, B. Chevalier, B. Darriet \\ Published in Journal of Alloys and Compounds 2002, vol. 330-332, p. 738-742.
}

\begin{abstract}
:
Reactive mechanical grinding (MG under $\mathrm{H}_{2}$ ) of magnesium powder improves the hydrogen sorption properties. The hydrogenation of $\mathrm{Mg}$ starts in situ during the milling process that allows suppressing the activation procedure generally requested for $\mathrm{Mg}$. The addition of $\mathrm{Co}$, which acts as a catalyst for the dissociation of $\mathrm{H}_{2}$, also leads to an improvement of the hydrogen sorption properties (but a strong dependence upon the milling time is reported). The hydriding is determined to be a two-step process: nucleation and diffusion. A direct relationship exists between the nucleation duration and the specific surface. A critical milling time exists below which the diffusion process is improved and above which no more improvement is observed (the maximum internal stress in the powder is also reached at this critical time). The diffusion is controlled by the number of crystallites per particle which can be decreased by increasing the milling time up to $10 \mathrm{~h}$. However, the sorption properties of $\mathrm{Mg}$-Co mixtures are a little under those reported for $\mathrm{MgH}_{2}$-metal mixtures.
\end{abstract}

\section{I ntroduction}

The slow hydrogen sorption kinetics of $\mathrm{Mg}$ and the high dissociation temperature of $\mathrm{MgH}_{2}$ strongly limit the practical applications [1] and [2]. Even so, $\mathrm{Mg}$ is one of the most promising candidates for a hydrogen storage material and a lot of research has been undertaken to overcome these drawbacks. The usual way is the addition to Mg of some metal or alloy by the use of high-energy ball milling (mechanical alloying [3]). Over the last 20 years, a large group of heterogeneous systems has been studied such as Mg-Fe [4], Mg-Ni [5], Mg- $\mathrm{LaNi}_{5}[6]$ and many others [7]. It has also been shown that mechanical grinding in a reactive atmosphere promotes the solid-gas reaction. Such a procedure has been used to produce nitrides, oxides and hydrides [8] at room temperature.

In a previous study [9] we found that, under our milling conditions, the Mg-Co system containing 10 wt.\% of Co exhibits the best sorption properties. With a view to application as electrodes in $\mathrm{Ni}-\mathrm{MH}$ batteries, addition of $\mathrm{Co}$ is well known to improve the cycling life of the electrode [10]. The aim of this study was to get a better understanding of the influence of reactive mechanical grinding (RMG) and Co addition on both the crystallographic and the hydrogen sorption behavior of the $\mathrm{Mg}+10 \mathrm{wt}$ \% Co mixture. In particular, our goal was to try to find the driving parameter of the nucleation and diffusion process.

\section{Experimental}

Pure Mg powder was mixed with Co (initial particle sizes of $50 \mu \mathrm{m}$ and 3-7 $\mu \mathrm{m}$, respectively, total weight $8 \mathrm{~g}$ ) in a stainless steel container (with 17 hardened steel balls, total weight $72 \mathrm{~g}$ ) closed in a hermetic way. All handling was performed in a glove box under Ar in order to prevent oxidation. The mill container was then evacuated to primary vacuum $\left(10^{-3} \mathrm{MPa}\right)$ prior to filling with high purity hydrogen gas $(\approx 1.1 \mathrm{MPa})$. The disc rotation speed was fixed to 200 rpm for all the experiments. The experimental procedure was as follow: 15 min of milling, $5 \mathrm{~min}$ of rest, $15 \mathrm{~min}$ of milling, refilling with $\mathrm{H}_{2}$ gas $(1.1 \mathrm{MPa})$. This procedure was repeated until the total milling time expected was reached. The procedure allows (i) prevention of leaks and (ii) increase in the $\mathrm{H} / \mathrm{M}$ ratio (initially $n_{\mathrm{H}} / n_{\mathrm{Mg}} \approx 0.2$ ).

The crystalline structure of as-milled powders was characterized by X-ray diffraction (XRD) analysis on a Phillips PW 1050 diffractometer using Bragg-Brentano geometry (CuKa radiation). These patterns were scanned by steps of $0.02^{\circ}$ $(2 \theta)$ from 25 to $80^{\circ}$ with counting time of $10 \mathrm{~s}$. The diffraction patterns were analyzed by a whole pattern fitting procedure (with the Thomson-Cox-Hastings function) using the program fullprof[11] in order to determine the lattice parameters, the weight concentration of each phase and both the crystallite size and the internal strain.

The hydriding apparatus has been described previously [12]. The sample chamber was evacuated to primary vacuum for $1 \mathrm{~h}$ without heating. The sample was then heated up to $350^{\circ} \mathrm{C}$ under $0.1 \mathrm{MPa}$ of hydrogen gas. When the temperature was stabilized, hydrogen gas was introduced into the sample chamber to a pressure of about $1.6 \mathrm{MPa}$. The absorbed hydrogen quantity was measured as a function of time by a volumetric method. 


\section{Results and discussion}

\subsection{Structural and chemical study}

It has already been shown that the RMG (200 rpm and $\left.m_{\text {balls }} / m_{\text {powder }}=9\right)$ of $M g+10 \mathrm{wt} . \%$ Co result in the formation of a mixture of $\mathrm{MgH}_{2}, \mathrm{Mg}$ and Co [9]. The amount of $\mathrm{MgH}_{2}$ formed is successfully calculated using Rietveld refinement. However, when the RMG duration was increased beyond $10 \mathrm{~h}$, the crystallinity of the mixtures decreased and the XRD method fails to determine precisely the $\mathrm{MgH}_{2}$ content. The use of a thermogravimetric method is then used to determine the fraction of $\mathrm{Mg}$ transformed into $\mathrm{MgH}_{2}$. This method leads to a larger uncertainty for the experiments at 15 and $20 \mathrm{~h}$. In Table 1, we summarize the results of the crystallographic and thermogravimetric experiments. It appears that $\mathrm{Mg}$ remained present even for long periods of RMG (up to $20 \mathrm{~h}$ ). The formation of $\mathrm{MgH}_{2}$ seems to be rapid during the first $10 \mathrm{~h}$ but slow thereafter. The diffraction patterns did not reveal any change in the lattice parameters (see Table 1) indicating that, as expected (i) almost no solid solution of $\mathrm{H}$ in $\mathrm{Mg}$ exists and (ii) the stoichiometry $\mathrm{H} / \mathrm{Mg}$ for $\mathrm{MgH}_{2}$ is strictly equal to 2. No formation of the ternary hydride $\mathrm{Mg}_{2} \mathrm{CoH}_{5}$ is noticed as reported for $\mathrm{MgH}_{2}-\mathrm{Ni}$ and $\mathrm{MgH}_{2}-\mathrm{Fe}$ [13], [14] and [15]. However, the starting products for Liang et al. [13] was $\mathrm{MgH}_{2}$ as opposed to $\mathrm{Mg}$ in the present case. $\mathrm{MgH}_{2}$ that is formed in situ in our case does not exhibit the same microstructure as that used by Liang et al. [13]. Moreover, the milling apparatus and milling conditions are not the same so the resulting products can be different. However, we can expect that after a longer milling time some ternary $\mathrm{Mg}_{2} \mathrm{CoH}_{5}$ could be formed (but then it would be formed as an almost amorphous phase).

The XRD patterns show that the peaks related to $\mathrm{MgH}_{2}$ are broader than those of $\mathrm{Mg}$ indicating a difference in the size of the crystallites (Fig. 1). MG (MG under Ar atmosphere) induces a larger reduction of the crystallites size compared with RMG. As the milling conditions (and then the global milling energy) are the same in both cases we concluded that the exothermic formation of $\mathrm{MgH}_{2}$ provides some 'thermal' energy that increased the crystallites size. Then the decrease of crystallites size by ball milling is reduced by that exothermic reaction. For RMG experiments, increasing the milling duration beyond $10 \mathrm{~h}$ does not lead to significant changes in the crystallites size of either $\mathrm{Mg}$ or $\mathrm{MgH}_{2}$. As we already notice the same phenomenon on $\mathrm{MgH}_{2}$ formation, we concluded that the efficiency of milling beyond $10 \mathrm{~h}$ is low. The process of $\mathrm{MgH}_{2}$ formation could be assumed to be firstly the adsorption of hydrogen on particles created by crushing (fresh surface) and then diffusion of the adsorbed hydrogen into the metals to form metal hydrides. On the basis that the milling efficiency beyond $10 \mathrm{~h}$ is low, no fresh surfaces would be created and the formation of $\mathrm{MgH}_{2}$ would be considerably reduced.

The partition of Co in the $\mathrm{Mg}$ matrix is also important for the hydrogen sorption characteristics. The results of electron probe microanalysis reveals that a milling time of $2 \mathrm{~h}$ allows an almost random dispersion to be obtained even if it has been possible to observe again a few cluster of Co. The size of the Co clusters decreases rapidly with increasing milling time.

\subsection{Hydriding properties}

We have already published [9] a hypothesis on the mechanism of the absorption phenomenon. The plot $\mathrm{d} A / \mathrm{d} t=f(F)$ presented in Fig. 2, where $A$ is the wt.\% of hydrogen absorbed (which is equivalent to a graph $\mathrm{d} F / \mathrm{d} t=f(F)$ where $F$ is the fraction of $\mathrm{MgH}_{2}$ formed) and $t$ is the time (of hydrogenation), allows a better understanding of the influence of MG atmosphere. The rate of formation is initially steady, indicating that the reaction is controlled by nucleation process and afterwards, the reaction rate decreases rapidly indicating that the reaction is controlled by a diffusion process. The nucleation process exists even for the first cycle but it starts at $F \approx 0.4$ because of the in situ hydrogenation that happened during the RMG. The behavior reported for MG products is equivalent but in this case, the nucleation duration (length) is shorter. Moreover, during the first absorption cycle, the reaction rate was very slow and typical of a reaction controlled by nucleation and growth. The two-step behavior is only observed from the second cycle.

We also notice that the nucleation process duration increases slightly with the number of hydrogenation cycles. As reported in Table 2, a direct relationship between specific surface and nucleation length can be established. Such a direct relationship between the specific surface and the nucleation 'length' clearly establishes that the process involved in the first step of the hydrogenation is controlled by the surface (as the nucleation process is). As the number of hydrogenation cycles increases, the specific surface increases too (decrepitation phenomenon) which leads to an increase of the nucleation duration. Increasing the milling time increases the specific surface and then the nucleation length, however, once again, beyond $10 \mathrm{~h}$; the specific surface is not increased further. 
To characterize the second step process, we use a simple model (spherical moving boundary model [16]). The rate equation can be written as:

$$
\frac{\mathrm{d} F}{\mathrm{~d} t}=\frac{4 \pi r k D_{\mathrm{H}}\left(P_{0}^{1 / 2}-P_{\mathrm{eq}}^{1 / 2}\right)}{\left[(1-F)^{-1 / 3}-1\right]}
$$

and $C=k D_{\mathrm{H}}\left(P_{0}^{1 / 2}-P_{\mathrm{eq}}{ }^{1 / 2}\right)$ where $r$ is the crystallite radius, $k$ the rate constant which depends on temperature and pressure, $P_{\mathrm{o}}$ the applied pressure and $P_{\mathrm{eq}}$ the equilibrium pressure (calculated according to the thermodynamic properties published by Liang et al. [17] i.e. In $\left.P_{\mathrm{eq}}=-74400 / R T+133.5 / R\right)$.

In order to compare all the mixtures, we take the Mg RMG for $2 \mathrm{~h}$ as a reference product and we normalized the $C$ value estimated for the ( $\mathrm{Mg}+10 \mathrm{wt} . \% \mathrm{Co})$ mixture by the $C$ value calculated for this reference. Then, as the milling conditions are the same for all experiments and as, at given temperature and pressure, $k$ and $\left(P_{0}^{1 / 2}-P_{\mathrm{eq}}{ }^{1 / 2}\right)$ should be constant (even if some dependence on the milling time exists) comparison of the normalized $C$ values gives us the opportunity to compare the diffusion process. The results are summarized in Table 3.

The diffusion is improved by increasing the milling time up to $10 \mathrm{~h}$ as expected from the creation of defects. Beyond $10 \mathrm{~h}$, the milling has been reported to be almost ineffective (no more internal stress generated) and so no more improvement of the diffusion constant is observed. Moreover, the Co addition does not improve the diffusion process - that means that the $3 \mathrm{~d}$ element acts as a catalyst for the dissociation of $\mathrm{H}_{2}$ as reported elsewhere [4], [9] and [18]. The use of RMG (compared with MG) leads to the larger improvement of the diffusion process. In the case of RMG, we established a linear relationship between the number of crystallites per particles and the normalized coefficient (Fig. 3). This relationship does not exist for the MG product suggesting two different behaviors. To a first approximation, we could conclude that the driving force of diffusion in the case of MG product is the intragrain diffusion as shown by Zaluska et al. [19] as in the case of the RMG product the intergrain diffusion should not be considered as negligible.

The dehydriding process was not extensively studied. However, the results of dehydrogenation as a function of temperature are shown in Fig. 4. The RMG improves significantly the dehydriding kinetics. Due to the strong dependence of the kinetics behavior upon the driving force (i.e. $\left(P_{0}-P_{\text {eq }}\right)[20]$ ), it is not easy to compare our results which some previous ones. Even so, the kinetic behavior reported by Liang et al. [20] is a little better than ours.

\section{Conclusion}

It is reported in this paper that a two-step process can describe the hydrogen absorption of a mixture $\mathrm{Mg}+10 \mathrm{wt} . \%$ Co elaborated by RMG. The first one is a nucleation process and the second step is a diffusion process. Both the nucleation and the diffusion processes can be improved by increasing the milling duration (creation of defects for nucleation and decrease of the number of crystallites per particle for diffusion) up to $10 \mathrm{~h}$. When the milling duration increase beyond $10 \mathrm{~h}$ the milling is ineffective and the hydrogen sorption properties barely improve.

It is therefore shown that the RMG process is an effective way of improving the sorption properties as it leads to an embrittlement of magnesium (decrease the particles size) without decreasing the crystallites size too much. It also allows the activation procedure (which is generally required prior to the first absorption reaction) to be suppressed. However, results published elsewhere [17], [19] and [20] using $\mathrm{MgH}_{2}$ as a starting material are always slightly better than our results. Some experiments are underway on the $\mathrm{MgH}_{2}-\mathrm{Co}$ mixture submitted to RMG.

\section{References}

1. H. Nagai, H. Tomizawa, T. Ogasawara, W. Shoji, J. Less-Common Met., 157 (1990), p. 15.

2. N. Gerard, S. Ono, L. Schlapbach (Ed.), Hydrogen in intermetallic Compounds II, Springer-Verlag (1992), p. 178.

3. E. Gaffet, O. Tillement, Ann. Chim. Sci. Mat., 22 (1997), p. 417.

4. I.G. Konstanchuk, E.Y. Ivanov, M. Pezat, B. Darriet, V.V. Boldyrev, P. Hagenmuller, J. Less-Common Met., 131 (1987), p. 181.

5. S. Orimo, K. Ikeda, H. Fuji, K. Yamamoto, J. Alloys Comp., 260 (1997), p. 143.

6. M. Terzieva, M. Khrussanova, P. Pechev, D. Radev, Int J. Hydrogen Energy, 20 (1) (1995), p. 53. 
7. G. Alefed, J. Volkl, Hydrogen in Metals, Springer, Berlin (1978), p. 1.

8. J-L. Bobet, C. Even, Y. Nakamura, E. Akiba, B. Darriet, J. Alloys Comp., 298 (2000), p. 279.

9. J-L. Bobet, E. Akiba, B. Darriet, Int. J. Hydrogen Energy, 25 (2000), p. 987.

10. T. Sakai, K. Oguro, H. Miyamura, N. Kuriyama, A. Kato, H. Ishikawa, C. Iwakura, J. Less-Common Met., 161 (1990), p. 193.

11. J. Rodriguez-Carjaval, Powder diffraction, Satellite meeting of the 15th Congress of IUCr, Toulouse, France (1990), p. 127.

12. J-L. Bobet, S. Pechev, B. Chevalier, B. Darriet, J. Mater. Chem., 9 (1999), p. 315.

13. G. Liang, J. Huot, S. Boily, A. VanNeste, R. Schulz, J. Alloys Comp., 292 (1999), p. 247.

14. S. Orimo, K. Fujii, J. Alloys Comp., 232 (1996), p. L16.

15. P. Tessier, E. Akiba, J. Alloys Comp., 293-295 (1999), p. 400.

16. M.Y. Song, J.Y. Lee, Int. J. Hydrogen Energy, 5 (1983), p. 363.

17. G. Liang, J. Huot, S. Boily, A. Van Neste, R. Schulz, J. Alloys Comp., 291 (1999), p. 295.

18. H. Aoyagi, K. Aoki, T. Masumoto, J. Alloys Comp., 231 (1995), p. 810.

19. A. Zaluska, L. Zaluski, J.O. Ström-Olsen, J. Alloys Comp., 288 (1999), p. 217.

20. G. Liang, J. Huot, S. Boily, R. Schulz, J. Alloys Comp., 305 (2000), p. 239. 
Table 1

Cell volume and wt. $\%$ of $\mathrm{MgH}_{2}$ formed for the mixture $(\mathrm{Mg}+10$ wt. $\%$

Co) submitted to RMG for various durations as reported in [9]

\begin{tabular}{|c|c|c|c|}
\hline \multirow{2}{*}{$\begin{array}{l}\text { Milling } \\
\text { time (h) }\end{array}$} & \multicolumn{2}{|c|}{ Cell volume $\left(\AA^{3}\right)$} & \multirow{2}{*}{$\begin{array}{l}\text { Fraction of } \mathrm{MgH}_{2} \\
\text { formed }\end{array}$} \\
\hline & $\mathrm{Mg}$ & $\mathrm{MgH}_{2}$ & \\
\hline 0 & 46.6 & - & 0 \\
\hline 2 & 46.5 & 61.3 & 10 (1) \\
\hline 5 & 46.5 & 61.7 & $47(2)$ \\
\hline 10 & 46.5 & 61.7 & 71 (3) \\
\hline 15 & 46.5 & 61.6 & $75(7)$ \\
\hline 20 & 46.6 & 61.7 & $82(8)$ \\
\hline
\end{tabular}

Table 2

Duration of the nucleation process and specific surface area as a function of experimental procedures for the (Mg +10 wt.\% Co) mixture submitted to $\mathrm{RMG}$ for different times

\begin{tabular}{|c|c|c|c|c|c|c|}
\hline & \multicolumn{6}{|c|}{ Experimental procedure ${ }^{a}$} \\
\hline & $\begin{array}{l}\text { RMG } 2 \text { h } \\
\text { Abs } 1\end{array}$ & $\begin{array}{l}\text { RMG } 2 \text { h } \\
\text { Abs } 2\end{array}$ & $\begin{array}{l}\text { RMG } 2 \text { h } \\
\text { Abs } 5\end{array}$ & $\begin{array}{l}\text { RMG } 5 \text { h } \\
\text { Abs } 2\end{array}$ & $\begin{array}{l}\text { RMG } 10 \text { h } \\
\text { Abs } 2\end{array}$ & $\begin{array}{l}\text { RMG } 15 \mathrm{~h} \\
\text { Abs } 2\end{array}$ \\
\hline Specific surface $\left(\mathrm{m}^{2} / \mathrm{g}\right)$ & 0.4 & 0.42 & 0.55 & 0.62 & 0.92 & 0.94 \\
\hline Nucleation 'length'b & 0.54 & 0.56 & 0.64 & 0.6 & 0.7 & 0.7 \\
\hline
\end{tabular}

a Abs $n$ refers to the $n$th absorption cycle.

${ }^{b} F$ value for which the diffusion process starts and the nucleation process stops.

Table 3

Estimated diffusion constant $\left[C=k D_{\mathrm{H}}\left(P_{0}^{1 / 2}-P_{\text {eq }}^{1 / 2}\right)\right]$ normalized by the $C$ value of $\mathrm{Mg}$ submitted to $\mathrm{RMG}$ for $2 \mathrm{~h}$; also included are morphologic (specific surface and particles size) and crystallographic (crystallites size) data

\begin{tabular}{|c|c|c|c|c|c|c|c|c|}
\hline & $\begin{array}{l}\mathrm{Mg} \mathrm{RMG} \\
2 \mathrm{~h}\end{array}$ & $\begin{array}{l}\text { RMG } \\
1 \mathrm{~h}\end{array}$ & $\begin{array}{l}\text { RMG } \\
2 \mathrm{~h}\end{array}$ & $\begin{array}{l}\text { RMG } \\
5 \mathrm{~h}\end{array}$ & $\begin{array}{l}\text { RMG } \\
10 \mathrm{~h}\end{array}$ & $\begin{array}{l}\text { RMG } \\
15 \mathrm{~h}\end{array}$ & $\begin{array}{l}\text { RMG } \\
20 \mathrm{~h}\end{array}$ & $\begin{array}{l}\mathrm{MG} \\
2 \mathrm{~h}\end{array}$ \\
\hline Normalized $C_{\mathrm{m}} / C_{\mathrm{Mg}}$ & 1 & 0.58 & 0.97 & 1.27 & 1.38 & 1.42 & 1.40 & 0.32 \\
\hline Specific surface $\left(\mathrm{m}^{2} / \mathrm{g}\right)$ & 0.46 & 0.24 & 0.42 & 0.62 & 0.92 & 0.94 & 0.93 & 0.17 \\
\hline Crystallites size $(\AA)$ & 37.0 & 39.0 & 38.1 & 36.0 & 33.0 & 32.3 & 31.8 & 29.0 \\
\hline Particles size $(\mu \mathrm{m})$ & 1.3 & 2.2 & 1.4 & 0.92 & 0.54 & 0.57 & 0.55 & 15 \\
\hline $\begin{array}{l}\text { No. of crystallites/ } \\
\text { particles }\end{array}$ & 35.1 & 56.4 & 36.7 & 25.5 & 16.4 & 17.6 & 17.3 & 517 \\
\hline
\end{tabular}




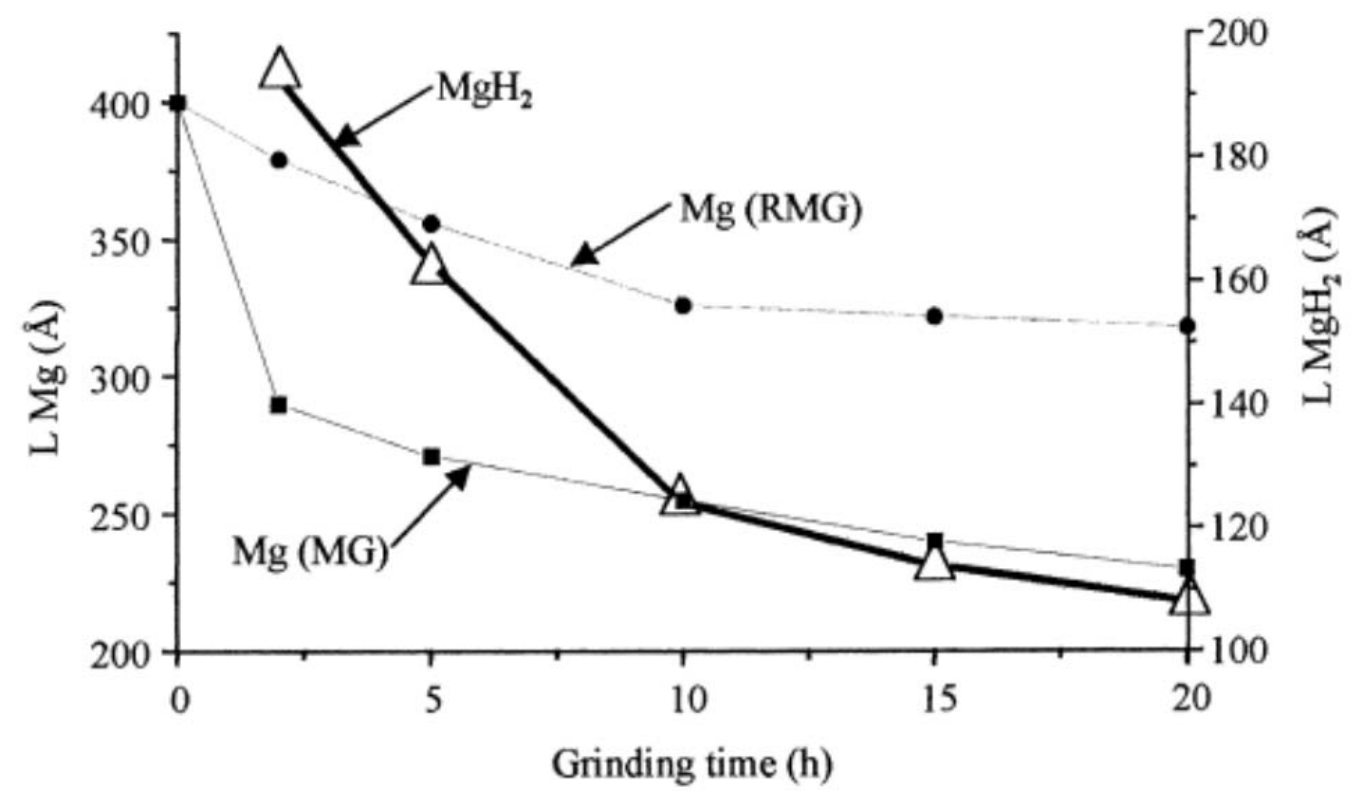

Fig. 1. Evolution of the crystallites size of both $\mathrm{Mg}$ (left axis) and $\mathrm{MgH}_{2}$ (right axis) as a function of the milling (or grinding) time.

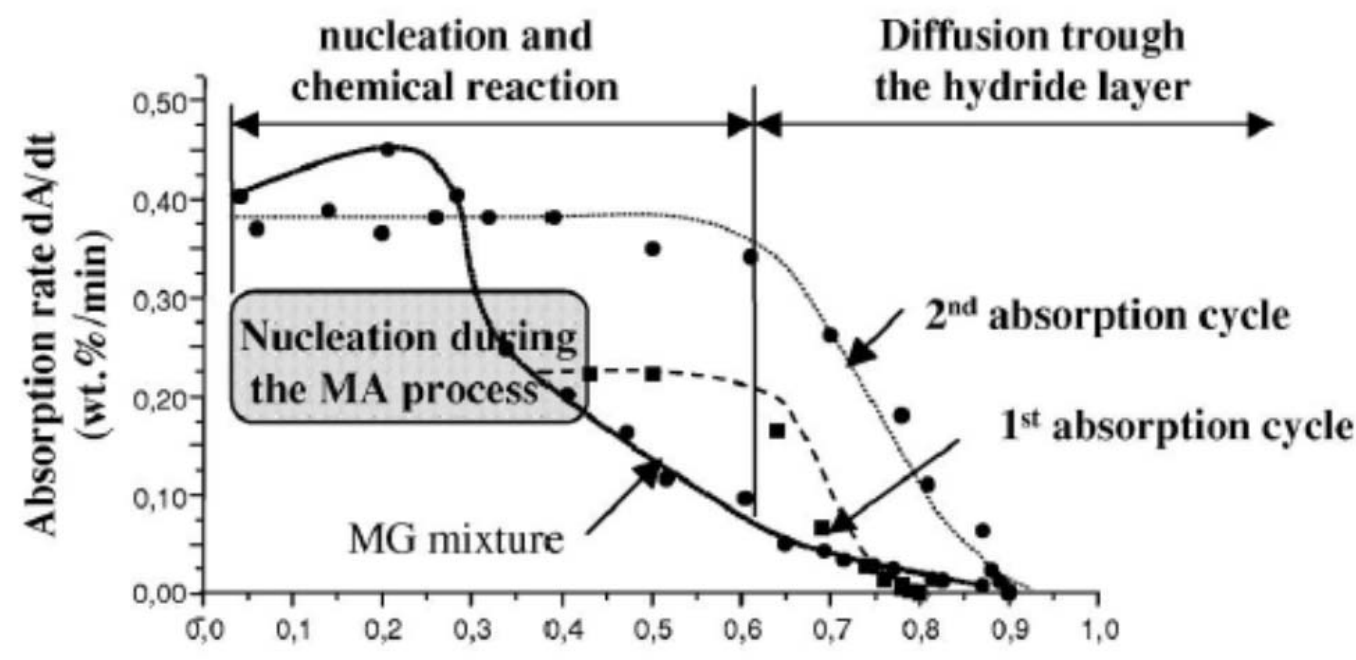

Transformed fraction $\mathbf{F}$

Fig. 2. Absorption rate for the products submitted to RMG and $M G$ (dotted line). 


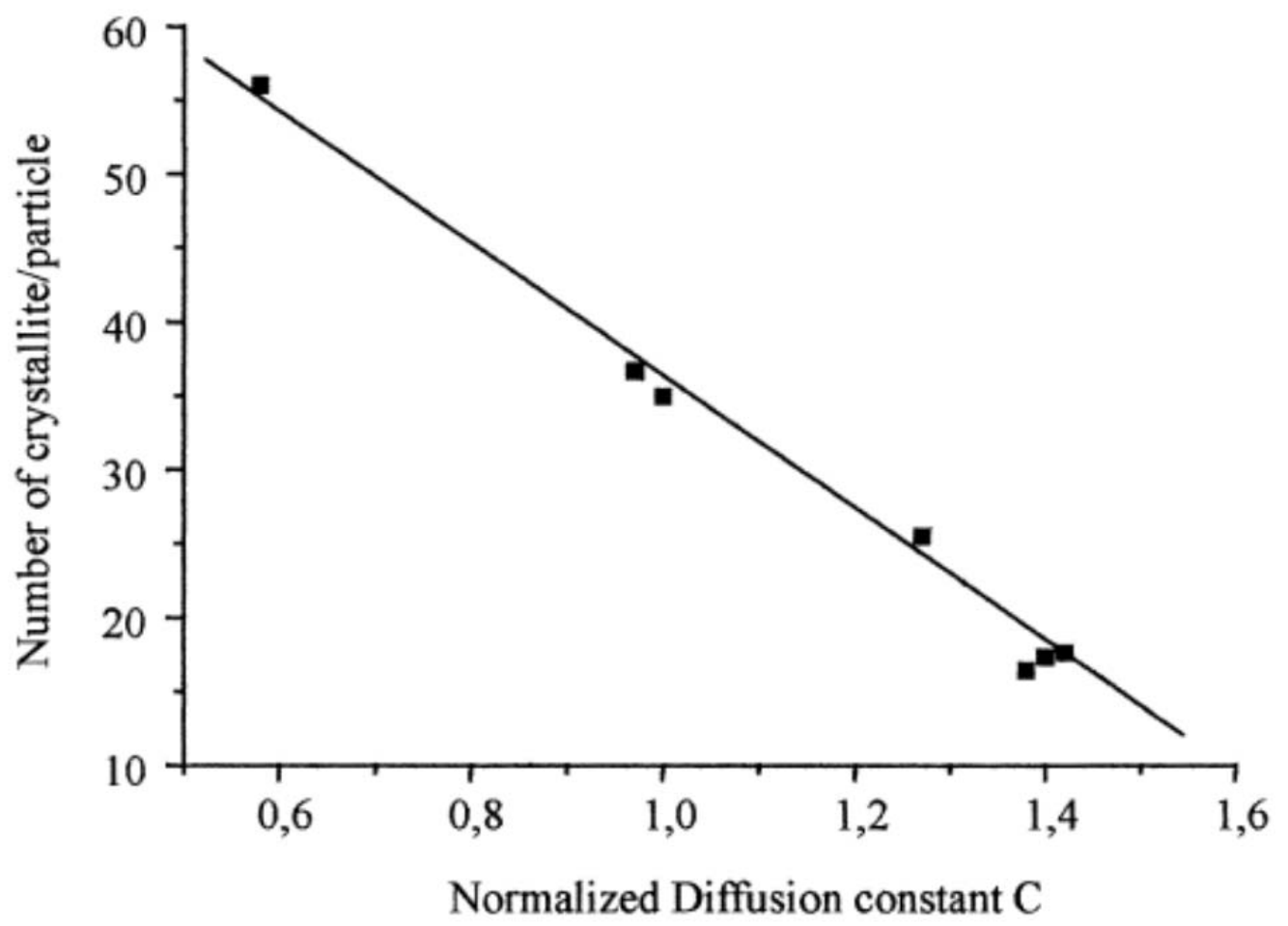

Fig. 3. Establishment of a linear relationship between the number of crystallites per particle and the normalized diffusion constant.

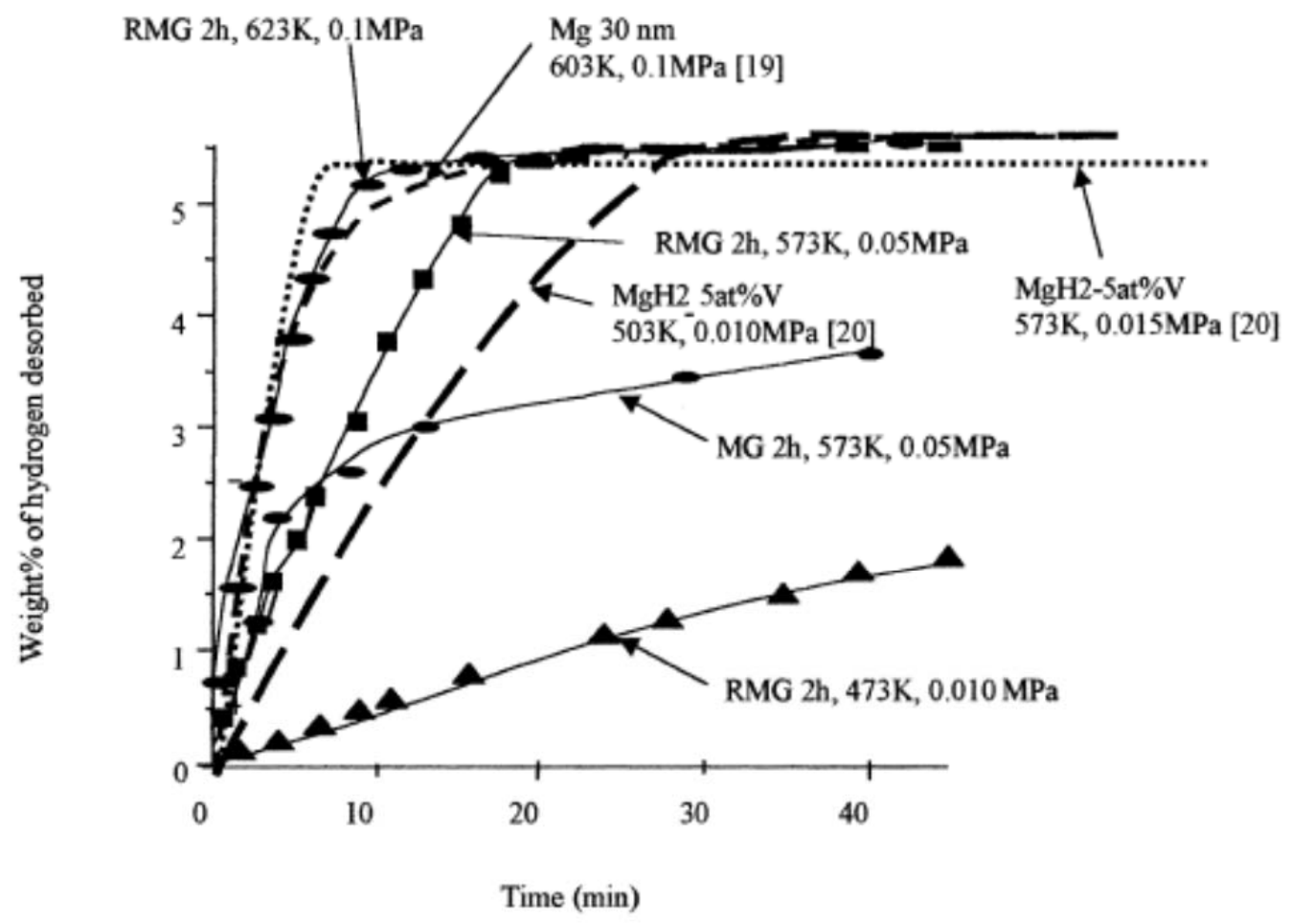

Fig. 4. Hydrogen desorption curves under various desorption pressure and temperature conditions for $\mathrm{Mg}+10 \mathrm{wt} \%$ Co subjected to the RMG or MG process. A comparison with the data obtained by Liang et al. [20] and Zaluski et al. [19] (both dotted lines) is included. 